\title{
Mental and social well-being versus physical disability - the diagnosis of the problems
}

\author{
Jadwiga Rzempowska', Monika Zysnarska², Barbara Stawińska-Witoszyńska², Jan Kłos², \\ Małgorzata Gromadecka-Sutkiewicz², Alicja Krzyżaniak², Tomasz Maksymiuk² \\ ${ }^{1}$ Faculty of Medicine, State University of Applied Sciences in Kalisz, Poland \\ ${ }^{2}$ Chair of Social Medicine, Poznan University of Medical Sciences, Poland
}

\begin{abstract}
Introduction. Health is most frequently defined as full well-being in the biological, psychological and social sense. A disorder of a person's functioning in any of these spheres triggers changes in the remaining ones. Such destabilization may result in losing the ability to cope with everyday situations.

Aim. The objective of the study was to recognize the self-assessment of the mental well-being, along with the selected elements of the social situation, of young, physically impaired persons living in the countryside.

Materials and Methods. The research was conducted on the population of physically disabled individuals with legally granted disability class, living in the countryside in the Wielkopolskie province, aged 18-45 years. The applied technique was an interview based on an original questionnaire with 96 questions.

Results. Over a half of the respondents confirmed that their disability affects their mental state. They often suffer from depressed mood, feeling of loneliness, feeling of being a "burden" for others. As many as $41.7 \%$ of respondents admitted suicidal thoughts.

Conclusions. The situation of disabled people living in the countryside is particularly difficult. Financial problems, unemployment, limited access to health care negatively influence the mental well-being of young persons, often leading to a depressed mood. In consequence, they often experience suicidal thoughts.
\end{abstract}

Keywords: mental well-being; social well-being; physical fitness; physical disability.

\section{Introduction}

The perception of health affects a person's well-being and their activities of daily life and also shapes their pro-health behavior. Health as a person's both potential and a quality is a disposition enabling them to adaptively function in a specific environment. It is perceived as a developmental-functional category and a resource conditioning comprehensive human development and enabling them to face current challenges. Health is a positive value that should be aimed at. If it occupies a high position in a person's or a social group's hierarchy of values, it is an essential decision-making element in human life, enabling individuals to choose behaviors convergent with their life style [1].
The concept of physical health refers to the body, the biological functioning of the organism and its particular systems. As far as mental health is concerned, it consists of two components. One of them, mental health, is defined as the ability to clearly and coherently think, learn and implement one's intellectual potential. The other component, emotional health, refers to the ability to control one's emotions and to express them in a way adequate for the situation. Moreover, it is also the capability of coping with difficulties [2]. Dynamic balance and health potential are the essence of both these areas. Balance reflects normal relations between spheres of a person's functioning, so disturbing any of these spheres will disrupt also the remaining 
ones. A condition of obtaining this balance is the health resource adequate for a person and his/her environment [3]. Nevertheless, it should be remembered that different environments (e.g. urban and rural) are characterized by different opportunities, requirements and barriers to functioning $[4,5]$.

\section{Aim}

The general objective of the study was to recognize the self-assessment of the mental well-being, as well as selected elements of the social situation of young, physically disabled people living in the countryside. Particular attention was paid to the consequences of the disability, suicidal thoughts, problems with the acceptance of one's own impairment, as well as the opportunities of obtaining help.

\section{Material and the methods}

The research was conducted on the population of physically disabled persons living in the countryside in the Wielkopolskie province.

By means of the stratification method, Kluczbork district and two communes: Koźminek i Lisków, were selected for the research. The main selection criteria were: age 18-45 years, legally confirmed disability, residence in Koźminek or Lisków commune, as well as the agreement for the participation in the research. Before the research, the documentation provided by the District Family Assistance Center in Kalisz was analyzed, with a view to select persons with physical disability who meet the earlier accepted criteria. After the analysis of the collected information, a group of 245 subjects was formed. The participation in the research was voluntary and anonymous. Before the research respondents filled out a form of conscious agreement. Out of the selected group 64 individuals did not meet the criterion of the type of disability (they were mentally disabled), and 6 did not agree to take part, giving the reason of the lack of time. Finally, 175 persons were included in the research, which accounts for $96.7 \%$ of all the subjects selected for the research - in accordance with the criteria.

The theoretical foundation of the study and the selection of the research method was the functional definition of disability - International Classification of Functioning (ICF), or International Classification of Impairments, Disabilities and Handicaps (ICIDH) -2 $[6,7]$.

The research was conducted in 2009. The interview technique was used, on the basis of an original tool a questionnaire consisting of 96 questions.
A pilot study was carried out on a group of 20 disabled persons. It turned out that the respondents had problems with answering some of the open questions. Adequate corrections were made.

The obtained information was subject to statistical analysis. All the calculations were conducted by means of Statistica 8.0 program made by StatXact. In the nominal scale the groups were analyzed with the help the chi square test $\chi 2$ (chi2). In the case of tables larger than $2 \times 2$ and the occurrence of observed zero numbers, the Fisher-Freeman-Halton test (FFHT) was applied. 5\% non sequitur was accepted. The tests were analyzed at the significance level $\alpha=0.05$.

\section{Research results}

\section{The demographic - social characteristics}

Among the 175 disabled countryside residents who participated in the research, men accounted for $46.1 \%$ and women - for $53.9 \%$. The disabled persons in the age group 40-45 years were most numerously represented. Disabled subjects accounted for $11.2 \%$ of all the residents of the researched area.

By far the largest group among the studied impaired individuals were married persons, 107 individuals in total, i.e. $61.1 \%$; there were 60 bachelors and maidens (34.3\%), 7 divorced persons (4.0\%) and 1 widower $(0.6 \%)$. Among the unmarried persons, there was the highest number of the youngest respondents in the age groups $18-24$ and $25-29$ years (56.6\%). Divorced persons belonged only to the age group 40-45 years. Also in this group there was the only widower.

The majority of the respondents had elementary education (59\%), the second biggest group had vocational education (25\%). 24 persons declared secondary education (14\%), and $3(2 \%)$ respondents - university education.

In the majority of cases $(97.7 \%)$ the respondents did not live on their own and did not run their households singlehandedly. $41.1 \%$ of the research participants did not have children.

The most frequently raised problems were those difficult to solve. Among others, these were: financial difficulties, no apartment or poor living conditions, illness or disability of other family members, unemployment, conflicts (however, 67\% of respondents defined the relations in their families as "good"), alcohol abuse in the family, lack of assistive devices.

Financial difficulties (for 60\% of respondents the per capita income was not higher than 500 zlotys, depending on: gender - men earned more than women $2=8.581938, p=0.0136$, education - the 
higher the education, the higher the declared income FFH $p=0.0001$, as well as the cause of the disability - persons with the inborn impairment had the lowest earnings $\chi 2=21.33457, p=0.00002$ ) - did not motivate respondents to try to increase their income by taking a job. In the majority of cases, disabled persons had sources of income other than work - pensions, allowances. The above mentioned decision was related to: age $(\chi 2=19.29, \mathrm{df}=8, \mathrm{p}=0.0133)$, education (TFFH $p=0.0148)$, the cause of disability $(\chi 2=13.63$, $\mathrm{df}=4, \mathrm{p}=0.0085)$ and the age at which the impairment occurred ( $\chi 2=16.098, d f=4, p=0.0028)$. In general, work was the source of income for subjects from the age group 25-29 years, with the university or secondary education. Illness and the older age of becoming disabled were the factors inclining respondents towards income forms other than work. It was also observed that for almost half of the respondents (49.7\%), the disabled person's individual income was the only source of income for the whole household. It should be noted, however, that due to disability 74 persons $(42.3 \%)$ were forced to resign from work and 29 respondents (16.6\%) had to change a job.

\section{The characteristics of the disability}

In the researched population there were individuals with inborn (13.1\%) and acquired - diseases, accidents (86.9\%) - physical dysfunctions. The most frequent causes of the acquired disability were the diseases of the musculoskeletal system (21.7\%), circulatory system (13.7\%) and nervous system (9.7\%). The musculoskeletal diseases were three times more common for women than men. However, circulatory diseases were the more frequent cause of disability for men. As for the degree of disability, the largest group of respondents had moderate degree of disability (48.5\%), the second largest was the group with the high degree $(26.9 \%)$ and the smallest group - those with the low degree of disability (24.6\%). The most common age of occurrence of impairment was over 30 years (46.9\%). One third of the male respondents and a half of the female ones also suffered from a chronic disease, apart from their disability.

\section{Mental well-being vs. selected factors affecting} the acceptance of disability

Disability exerts a negative influence on a person's mental well-being. Disability, as a difficult experience,

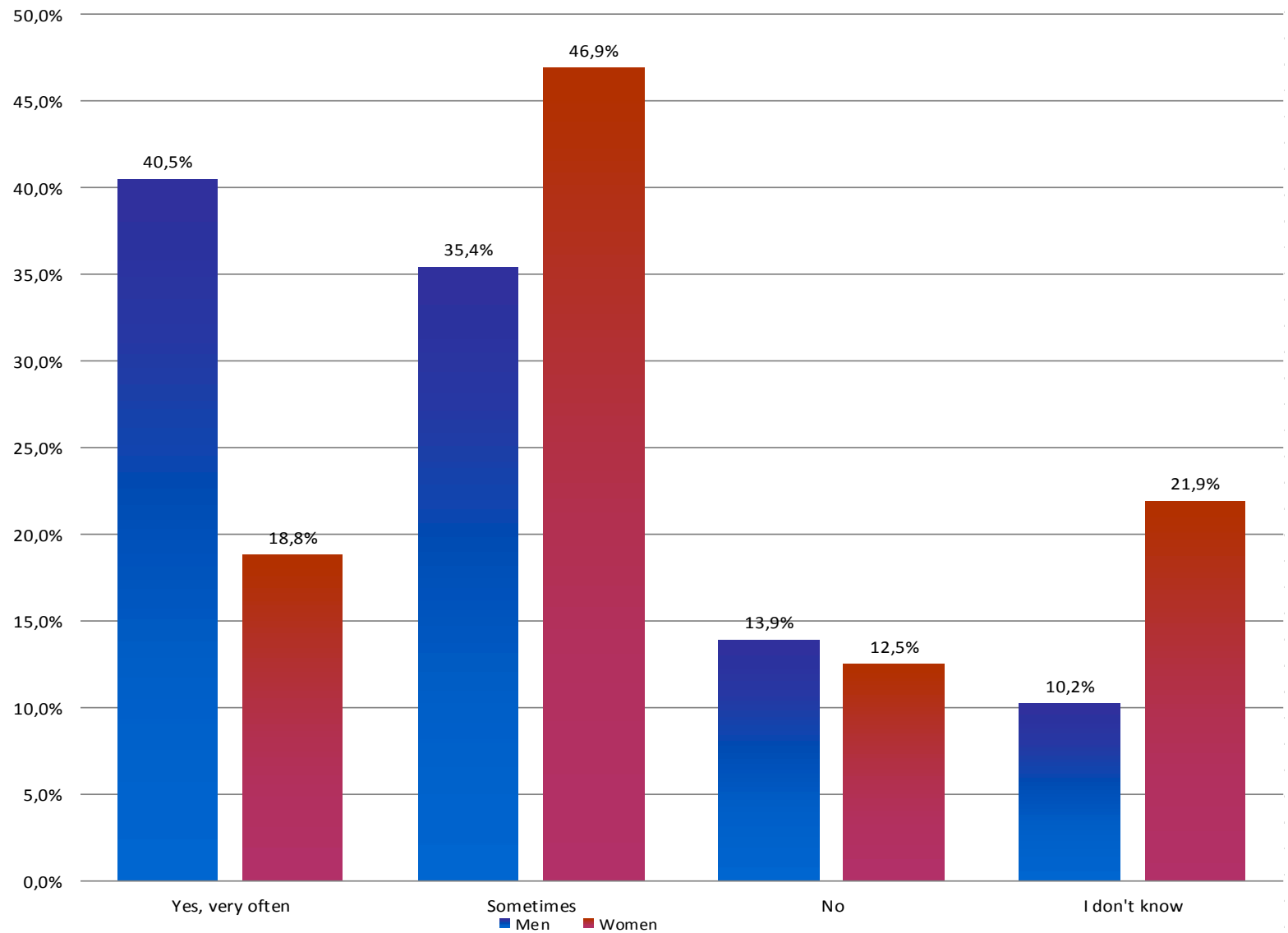

Figure 1. The influence of disability on the mental state of respondents - depending on the gender 
may lead to an emotional collapse, anxiety and loneliness. Over a half of the studied disabled people confirmed that their disability affected their mental state.

\section{(cf. Figure 1).}

The influence of disability on the mental state was similar for men and women ( $p=0.1369)$. The respondents were also asked about the occurrence of such states as: loneliness, being a burden for others, feeling of loss, and lack of sense of life; they could also describe their feelings within the option: "other". The respondents stated that they saw their disability as a burden for others $(25.1 \%)$ and $16.6 \%$ of the respondents had a feeling of lost life. The research results also showed that $13.1 \%$ of the disabled persons had a permanent feeling of loneliness. The "other" category (it meant: "mental discomfort", "isolation", helplessness", "lack of communication with the family", "debility", "powerlessness", "irritability", "lack of self-confidence", "lack of independence", "lack of trust" and "lack of understanding") was chosen most frequently (36\% of respondents). Among men, the highest proportion of respondents marked the answers: "other" (36.7\%) and "everything is lost" (27.8\%). As for women, the highest percentage selected the answers: "other" and "being a burden for others" (35.4\% and 34.3\%, respectively).

It also turned out that in a large number of cases, the depressed mood was accompanied by suicidal thoughts. As many as $41.7 \%$ of respondents admitted to having them. The frequency of their occurrence was the same for men and women, regardless of biological age, the age of becoming impaired, marital status, or education ( $p>0.05$ ). The application of the test for independence $\chi 2$ allowed the authors to find out that there was a dependency between the cause of impairment and the occurrence of suicidal thoughts (Figure 2).

Suicidal thoughts were the most frequent for persons with post-traumatic disabilities.

Although respondents indicated that their periods of depressed mood were temporary, $9.7 \%$ of them stated that they had never accepted their disability.

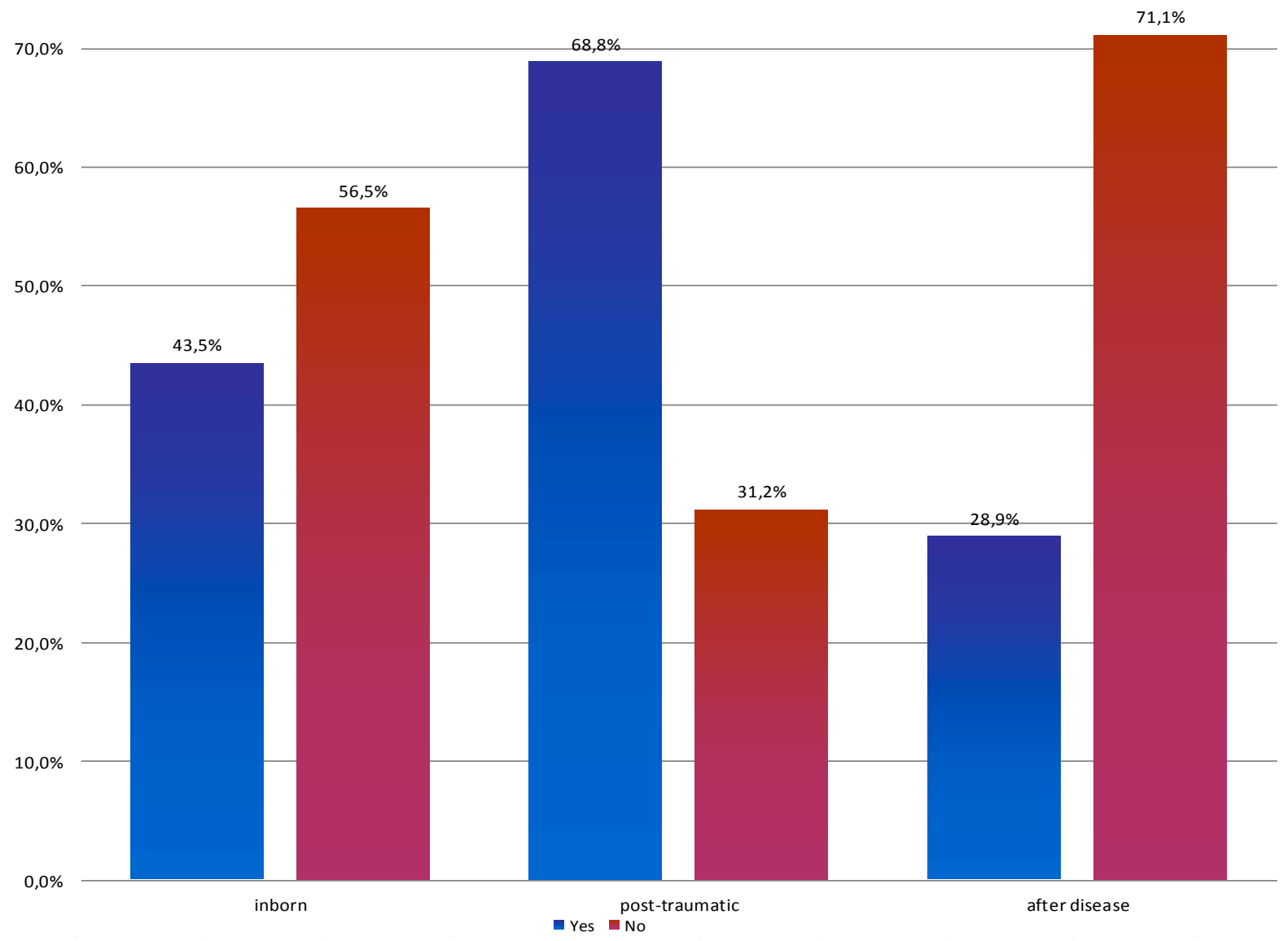

Figure 2 . The cause of disability versus the frequency of occurrence of suicidal thoughts 
The statistical analysis showed that, among the studied factors, only education influenced the degree of acceptance of a person's own disability (Table 1).

Respondents with the university education more often than others could not come to terms with what had happened to them ( $p=0.0027$ ). The majority of the research participants $(81.7 \%)$ also stated that although sometimes it was hard for them to accept the reality, they loved themselves as they were. It should be underlined that as many as $18.3 \%$ of the respondents did not accept their disability.

All the respondents reported the occurrence of situations which negatively affected their mood. They used the following effective methods to minimize the effects of this discomfort: pain-relieving medicines $-88.6 \%$ of men and $67.7 \%$ of women (gender did not have an influence on the frequency of taking painkillers, $p=0.3468$ ), alcohol (men more often than women, $p=0.0074$, as well as persons with post-traumatic disabilities, $p=00001$ ) and cigarettes (smoking men definitely outnumbered smoking women, $p=0.0000)$.

\section{The assessment of the employment situation}

As many as $47.2 \%$ of all the respondents evaluated their situation on the labor market as bad $(48.1 \%$ men and $46.9 \%$ women). The opinions varied in relation to the age of the disabled people (TFFH $p=0.0330$ ). In the group of respondents negatively assessing their situation on the labor market the majority belonged to the oldest age group of $40-45$ years (58.5\%), and the lowest number - to the 25-29 years age group (28.6\%). Furthermore, the highest proportion of both the disabled participants with elementary education $(p=0.0001)$ and those who became impaired after the age of 30 years $(p=0.0140)$ negatively assessed their employment situation. However, the research did not show any relationship between the evaluation of the employment situation and the marital status $(p=0.610)$, or the cause of disability $(p=0.2040)$.

\section{Social life and support}

The social well-being was researched from the view point of the social life, as well as the disabled person's chance of obtaining support. In the vast majority of cases the

Table 1. The acceptance of one's own disability in relations to: age, education, marital status, the cause of disability and the age of acquiring it

\begin{tabular}{|c|c|c|c|c|c|c|c|c|}
\hline \multirow{3}{*}{\multicolumn{2}{|c|}{ The studied variable }} & \multicolumn{6}{|c|}{ Acceptance of one's own disability } & \multirow{3}{*}{$\begin{array}{l}\text { Statistical } \\
\text { analysis }\end{array}$} \\
\hline & & \multicolumn{2}{|c|}{ Yes } & \multicolumn{2}{|c|}{ No } & \multicolumn{2}{|c|}{ Total } & \\
\hline & & $\mathrm{N}$ & $\%$ & $\mathrm{~N}$ & $\%$ & $\mathrm{~N}$ & $\%$ & \\
\hline \multirow{6}{*}{ Age [years] } & $18-24$ & 16 & 76.2 & 5 & 23.8 & 21 & 100.0 & \multirow{6}{*}{$\begin{array}{c}\chi 2=2.37 \\
d f=4 \\
p=0.6212\end{array}$} \\
\hline & $25-29$ & 23 & 82.1 & 5 & 17.9 & 28 & 100.0 & \\
\hline & $30-34$ & 23 & 79.3 & 6 & 20.7 & 29 & 100.0 & \\
\hline & $35-39$ & 29 & 90.6 & 3 & 9.4 & 32 & 100,0 & \\
\hline & $40-45$ & 52 & 80.0 & 13 & 20.0 & 65 & 100.0 & \\
\hline & Total & 143 & 81.7 & 32 & 18.3 & 175 & 100.0 & \\
\hline \multirow{5}{*}{ Education } & elementary & 85 & 81.7 & 19 & 18.3 & 104 & 100.0 & \multirow{5}{*}{$\begin{array}{c}\text { TFFH } \\
p=0.0027\end{array}$} \\
\hline & vocational & 38 & 86.4 & 6 & 13.6 & 44 & 100.0 & \\
\hline & secondary & 20 & 83,3 & 9 & 16.7 & 24 & 100.0 & \\
\hline & university & 0 & 0.0 & 3 & 100.0 & 3 & 100.0 & \\
\hline & Total & 143 & 81.7 & 32 & 18.3 & 175 & 100.0 & \\
\hline \multirow{5}{*}{ Marital status } & single & 46 & 76.7 & 14 & 23.3 & 60 & 100.0 & \multirow{5}{*}{$\begin{array}{c}\text { TFFH } \\
p=0.4685\end{array}$} \\
\hline & married & 91 & 85.1 & 16 & 14.9 & 107 & 100.0 & \\
\hline & divorced & 5 & 71.4 & 2 & 28.6 & 7 & 100.0 & \\
\hline & widowed & 1 & 100.0 & 0 & 0.0 & 1 & 100.0 & \\
\hline & Total & 143 & 81.7 & 32 & 18.3 & 175 & 100.0 & \\
\hline \multirow{4}{*}{$\begin{array}{l}\text { Cause of } \\
\text { disability }\end{array}$} & inborn & 17 & 73.9 & 6 & 26.1 & 23 & 100.0 & \multirow{4}{*}{$\begin{array}{c}\chi 2=1.73 \\
d f=2 \\
p=0.4208\end{array}$} \\
\hline & accident & 38 & 79.2 & 10 & 20.8 & 48 & 100.0 & \\
\hline & disease & 88 & 84.6 & 16 & 15.4 & 104 & 100.0 & \\
\hline & Total & 143 & 81.7 & 32 & 18.3 & 175 & 100.0 & \\
\hline \multirow{4}{*}{$\begin{array}{l}\text { Age of } \\
\text { acquiring } \\
\text { disability } \\
\text { [years] }\end{array}$} & up to 18 & 24 & 80.0 & 6 & 20.0 & 30 & 100.0 & \multirow{4}{*}{$\begin{array}{c}\chi^{2}=1.44 \\
d f=2 \\
p=0.4857\end{array}$} \\
\hline & $19-30$ & 49 & 77.8 & 14 & 22.2 & 63 & 100.0 & \\
\hline & over 30 & 70 & 85.4 & 12 & 14.6 & 82 & 100.0 & \\
\hline & Total & 143 & 81.7 & 32 & 18.3 & 175 & 100.0 & \\
\hline
\end{tabular}




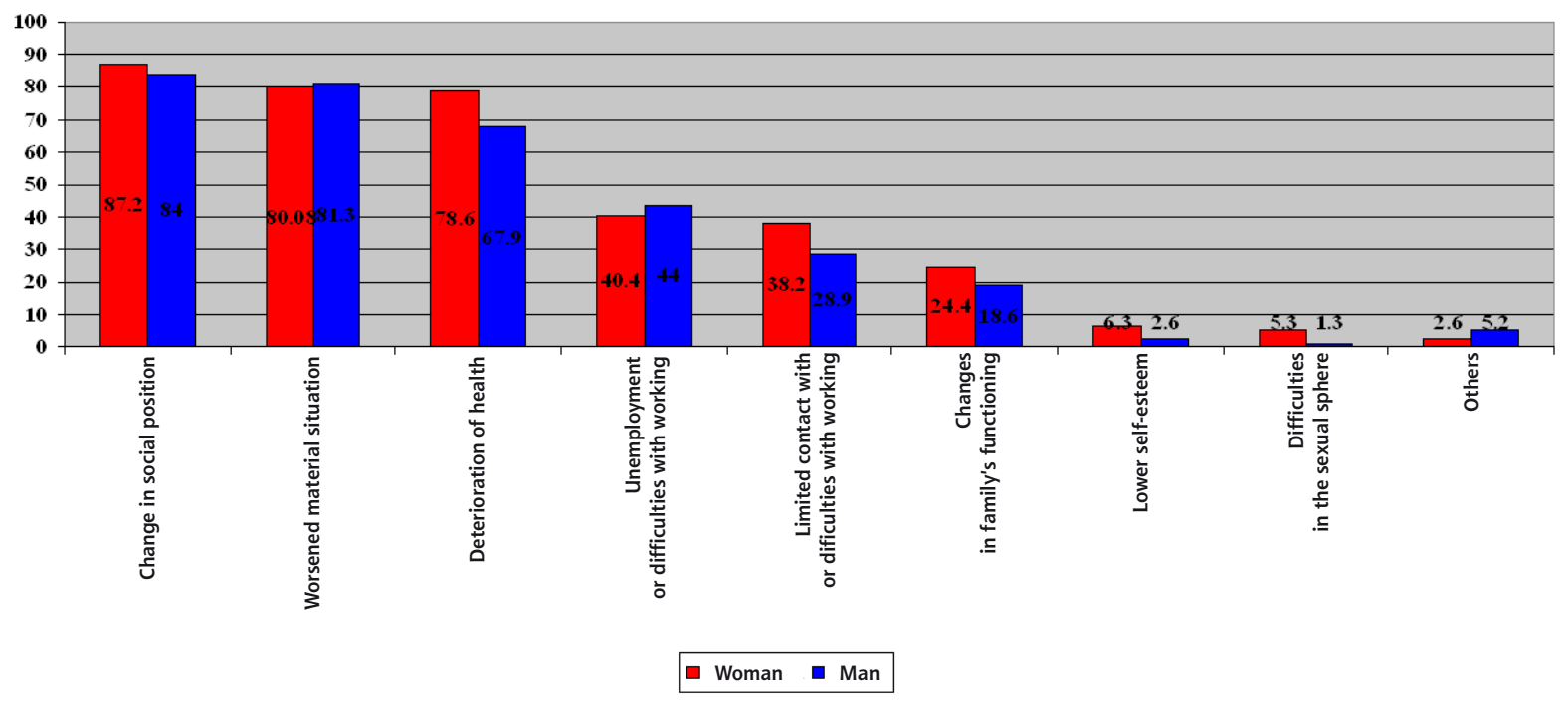

Figure 3. Consequences of disabilities. The results do not sum up to $100 \%$ because respondents could choose more than one answer

respondents declared that they had friends and acquaintances with whom they were constantly in touch. For $69 \%$ of participants, friends and acquaintances were mainly healthy people, for $9.9 \%$ of respondents - mainly disabled persons, whereas for the remaining $21 \%$ the proportions were approximately the same. Two sources of support were distinguished - individual and institutional. As far as the individual sources were concerned, the most common one were family members $54.2 \%$. As for the institutional sources, these were: the Communal Social Welfare Center - $15.4 \%$ and organizations for disabled persons $-7.4 \%$. It needs to be emphasized that $41 \%$ of the respondents claimed that there are no institutions or organizations which they can turn to for help. There was a statistically significant relationship between the assessed level of the offered support and the respondents' age $p=0.0071$. The level of support was negatively evaluated only by the oldest age group of 40-45 years (9.5\%). Also the cause of the impairment affected this evaluation ( $p=0.0007$ ). Persons with the inborn disability far more frequently (43.5\%) positively assessed the level of the received help than those whose disability was caused by an accident (8.3\%), or disease (8.7\%). Also single persons more positively evaluated such help than the married ones ( $p=0.0027)$. However in the light of the research there was no relationship between the evaluation of the received support and the gender $(p=0.2136)$, or the education ( $p=0.1515$ ) of the respondents.

The consequences of disability in the respondents' opinion The majority of respondents indicated a high frequency of consequences of their disability. Only 6 persons declared a lack of them (cf. Figure 3).
The definitely most frequently selected answer was the change of the social role and position. Only slightly less often mentioned ones were: worsening of the material situation and the deterioration of health.

\section{Discussion}

Diseases and accidents were the main causes of disabilities in the studied population. This conclusion is also was reflected in other publications [8-15]. Regardless of the cause of disability, for many years the emphasis has been placed on the optimal functioning of people - especially those with certain somatic or mental limitations. Research focuses mainly on the self-assessment of the state of health, as an important and independent predictor of the state of health, recommended by WHO $[16,17]$. In relation to the subjective assessment of health, there are various consequences of disability. $[18,19]$ They refer to many areas of human life and, among others, research conducted by A. Ostrowska and B. Szczepankowska [20] confirmed the material marginalization of the disabled. According to D. Gorajewska [21], another factor which negatively affects their well-being is the lack of chances for the professional development. This view is shared by Stelcer [21], in whose opinion the difficult material situation, as a consequence of impairment, not only lowers the standard of living, but also leads to difficulties in performing social roles. These theses are reflected in the results of conducted research.

As many as $75.9 \%$ of disabled men and $65.7 \%$ of disabled women admitted that their mental health had deteriorated (despite their families' support). It may result from the process of disordered adjustment to the 
reality. If the quality of life with disability is high, a person is capable of accepting the situation sooner, as they have a high self-esteem and the ability to achieve their life objectives. However, the accomplishment of the sense of security requires support from both the closest family and institutions. Research shows that social support is a prerequisite of disabled persons' effective activity and their achievement of life satisfaction. [23] In J. Kirenko's opinion, the successful adjustment of a disabled person depends on the question whether or not they accept their own dysfunction. It does not only mean coming to terms with one's own disability, but also the dynamic acceptance of the whole state, through the modification of their approach to themselves and the environment and, in consequence, developing skills and habits facilitating their change of lifestyle. [24] The lack of acceptance of somatic differences often leads to the disorder of the mental well-being, which is confirmed by the research. In addition, respondents emphasized the feeling of loneliness, being a burden for others and losing a sense of life. These statements have a special dimension in the light of the suicidal thoughts experienced by disabled people, which was confirmed by $41.7 \%$ of respondents. Other authors' research also shows that at least in the case of certain types of impairment, the suicide rate is considerably higher than for the population at large. The disabled individuals studied by the authors of this work were looking for solutions to the above mentioned problems, but since living in the rural areas is characterized by limited access to professional support, their activities often amounted to pharmaceuticals, alcohol and cigarettes. According to J. Kirenko $[26,27]$, unfortunately, there are many barriers and harmful stereotypes dividing the world of the healthy people and the impaired ones. Because of the lack of the social acceptance of being different, these people live in the fear of rejection. According to T. Lake [28], a big number of the disabled live in loneliness or "a certain isolation from others". The researched disabled inhabitants of the rural areas emphasize that their dysfunctions limit their activity and isolate them from the world. Research conducted by experts indicate that loneliness is one of the most significant factors influencing health $[29,30]$.

The main guidelines of the social policy towards disabled people aim at fighting all acts of discrimination and at organizing a state without barriers and without social exclusion. The society should "learn disability" in the sense of understanding the significance of the problem and undertaking attempts of introducing rational changes. It is essential, because disability infringes on individual's precious values: health and psychophysical efficiency, also makes it difficult or impossible to perform certain social roles. Nevertheless, as A. Hulek [31] said, "there is no disability which has taken more than left". These words should be a motto of the integration of disabled persons, aiming at eliminating barriers to their functioning, supporting their development and enabling them to achieve their life objectives. Unfortunately, at present functioning of these people, especially those living in the countryside, is hampered by such obstacles as: lack of acceptance of a different person, still common (also among the disabled themselves), conviction about the uselessness of disabled people, insufficient financial resources, as well as the lack of complex institutional solutions.

\section{Conclusions}

Over half of the respondents confirmed that their disability influences their mental condition, which is manifested by a feeling of loneliness, being a burden for others and lack of a sense of life.

The major consequences of disabilities are: the change of social role and position, worsened material and health situation, unemployment or difficulties with performing a job.

As many as $41.7 \%$ of the respondents declared the occurrence of suicidal thoughts. Such thoughts were more frequently experienced by persons with post-traumatic impairments than with the inborn ones.

Although all the respondents feel the burden of their disability, the majority of them $-81.7 \%$ accepted it. Persons with the university education have the greatest problems in accepting it.

The respondents reported that the main source of support is their family. The institutional support is much more limited.

The proposal resulting from the research is the need to immediately introduce measures to help disabled individuals, in order to improve both their social situation (professional development, better access to public institutions) and their mental well-being (self-acceptance, elimination of suicidal thoughts).

\section{Acknowledgements}

The authors are grateful to Natalia Spychała, M.Sc. who provided English translation.

\section{Conflict of interest statement}

The authors declare no conflict of interest.

\section{Funding sources}

There are no sources of funding to declare. 


\section{References}

1. Nowicki G, Ślusarska B. Determinanty społeczno-demograficzne wartościowania zdrowia wśród pracujących osób dorosłych. Hygeia Public Health. 2011;46(2):280-285.

2. Gitling M. Socjologiczne koncepcje zdrowia, choroby i niepełnosprawności. In: Niepełnosprawność i Rehabilitacja. Kwartalnik Instytutu Rozwoju Służb Społecznych. 3, lipiec-wrzesień. 2010:7-29.

3. Woynarowska B. Encyklopedia zdrowia. Wyd. PWN, Warszawa. 2008:28-31.

4. Maart S, Eide Arne Henning, Jelsma J, Loeb Mitchell, Ka Toni M. Environmental barriers experienced by urban and rural disabled people in South Africa. Disability \& Society. 06/2007;22(4):357-369.

5. lezzoni LI1, Killeen MB, O'Day BL. Rural residents with disabilities confront substantial barriers to obtaining primary care. Health Serv Res. 2006 Aug;41(4 Pt 1):125875.

6. International Classification of Functioning. Disability and Health. WHO, Genewa. 2001:110-160.

7. Majewski T. Międzynarodowa Klasyfikacja Funkcjonowania, Niepełnosprawności i Zdrowia. Praca i rehabilitacja niepełnosprawnych. 2008;4:119-120, 8-10.

8. Brzeski Z, Zagórski J. Narażenia na szkodliwe czynniki środowiska ludności zamieszkałej na obszarach wiejskich. Med Środowiskowa. 1998:1, 17.

9. Fornal R, Dworzański T, Jędrzejewska B. Epidemiologia urazów jako problem najbliższej przyszłości. In: Problemy rehabilitacyjne i zagadnienia pomocy społecznej osób niepełnosprawnych w Polsce. Tom II. Karwat ID. (eds.). Liber, Lublin. 2002:143-144.

10. Grys G, Uszyński H, Sawicki G, Orłowski J. Socjoekonomiczne następstwa obrażeń pourazowych ręki. Chir Narządu Ruchu i Ortopedia Polska. 1998;63(1):67-74.

11. Janiszewski Cz. Rozpowszechnienie chorób układu krążenia wśród mieszkańców z rejonu Gminnego Ośrodka Zdrowia w Wyrykach. Med Ogólna. 1998;4:4.

12. Karski JB. Statystyka wypadków w Polsce. Służba Zdrowia 6-10 grudnia. 2001;(94-95):3089-3090.

13. Kiwerski J. Współczesne poglądy na rehabilitację. In: Kiwerski J. (ed.). Rehabilitacja medyczna. Wydawnictwo Lekarskie PZWL, Warszawa 2005; 28-30.

14. Król M, Przybyłka A. Rynek pracy osób niepełnosprawnych. In: Frąckiewicz J. (ed.). Niepełnosprawni w środowisku społecznym. Wyd. AE, Katowice. 1999:143-183.

15. Krupa Sz, Karwat DI. Rodzaje urazów głowy a okoliczności wypadków. In: Problemy rehabilitacyjne i zagadnienia pomocy społecznej osób niepełnosprawnych w Polsce. Tom II. Karwat ID. (ed.). Liber, Lublin. 2002:127-130.

16. De Bruin A, Picavet HSJ, Nossikov A. Health interview surveys: Towards international harmonization of methods and instruments. European Series. 58, WHO Regional Publications, Copenhagen. 1996; 63-73.

17. Krause MN, Jay GM. What do Global Self-Rated Health Items Measure? Medical Care. 32(9):930-942.

18. Bickenbach JE. Minority rights or universal participation: the politics of disablement. In: Jones M, Marks LA (eds.). Disability, Divers - ability and Legal Change. The Hague: Kluwer Law International/Martinus Nijhoff Publishers. 1999; 101-115.

19. Garbat M, Paszkowicz MA. Jakość życia osób niepełnosprawnych w województwie lubuskim - diagnoza sytu- acji materialno-bytowej. In: Palak Z. (ed.). Jakość życia osób niepełnosprawnych i nieprzystosowanych społecznie. Wydawnictwo Uniwersytetu Marii Curie-Skłodowskiej, Lublin. 2006; 261-275.

20. Ostrowska A, Szczepankowska B. Aktywność zawodowa osób niepełnosprawnych - stan i potrzeby. In: Problem niepełnosprawności w poradnictwie zawodowym. Zeszyt informacyjno-metodyczny doradcy zawodowego. KUP, Warszawa 1998; 13-23.

21. Gorajewska D (ed.). Społeczeństwo równych szans. Tendencje i kierunki zmian. Integracja. Warszawa 2005; 10-24.

22. Stelcer B. Jakość życia jako pojęcie subiektywne i wielowymiarowe. Pielęgniarstwo Polskie. 2001;2:227-233.

23. Murray Ch, Lombardi A, Bender F, Gerdes H. Social support: main and moderating effects on the relation between financial stress and adjustment among college students with disabilities. Social Psychology of Education. June. 2013;16(2):277-295.

24. Kirenko J. Oblicza niepełnosprawności. Wydawnictwo Akademickie Wyższej Szkoły Społeczno-Przyrodniczej im. Wincentego Pola w Lublinie. Lublin. 2006;15-36:97106, 107-122.

25. Giannini MJ, Bergmark B, Kreshover S, Elias E, Plummer C, O'Keefe E. Understanding suicide and disability through three major disabling conditions: Intellectual disability, spinal cord injury, and multiple sclerosis. Disabil Health J. 2010 Apr;3(2):74-8. doi: 10.1016/j.dhjo.2009.09.001. Epub. 2009 Nov 3.

26. Kirenko J. Oblicza niepełnosprawności. Wydawnictwo Akademickie Wyższej Szkoły Społeczno-Przyrodniczej im. Wincentego Pola w Lublinie, Lublin 2006; 15-36, 97-106, 107-122.

27. Kirenko J. Wsparcie społeczne osób z niepełnosprawnością. Wyższa Szkoła Umiejętności Pedagogicznych i Zarządzania. Ryki 2002; 349-361.

28. Lake T. Samotność jak sobie z nią radzić. Warszawa. 1993:93.

29. Berkman LF, Glass T, Brissette I, Seeman TE. From social integration to health: Durkheim in the new millennium. Social Science \& Medicine. 2000;51(6):843-857.

30. Berkman LF, Glass T. Social integration, social networks, social support, and health, In: Berkman LF, Kawachi I. (eds.). Social epidemiology, Oxford University Press, New York 2000; 137-173.

31. Hulek A. Zawodowa rehabilitacja inwalidów. PZWL 1997; 56-167.

Acceptance for editing: 2016-03-15 Acceptance for publication: 2016-03-31

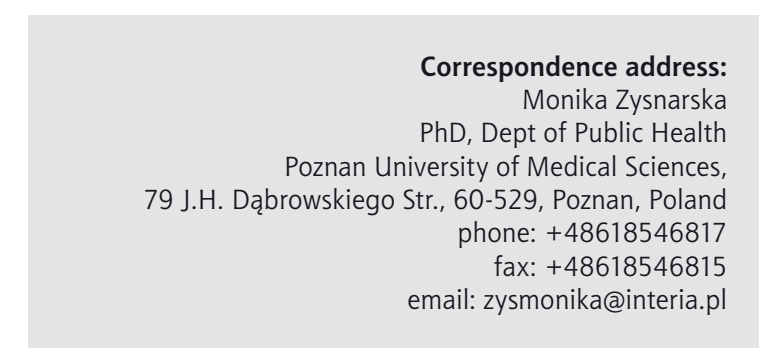

